\title{
Machine Cell Designing for Machinaries of Leather Shoes Production Unit
}

\author{
G. Santhoshkumar, Velanganni, S. Robin
}

\begin{abstract}
Career planning is the self-evaluation \& planning done by a person to have a strong career path. Career planning process in the continuous reiterative process of understanding oneself, setting career goals, revising skills and searching for the right career options. A career plan is an individual's choice of occupation, organization and career path. Career planning encourages individuals to explore and gather information, which enables them to synthesize, gain competencies, make decisions, set goals and take action.
\end{abstract}

Keywords: Career planning, competencies,

\section{INTRODUCTION}

Meaning

A person's career is nothing but a format of views held by him in the course of his work life.. This credentials of the individual and the needs of the organization must coincide for the former to have a profession.

Definition

The career of Edwin B. Flippo has been described as "a sequence of separate but related work activities that provide continuity, order and meaning in a person's life"

Career, thus, is an individually perceived sequence of attitudes and behaviors associated with work related experiences and activities over the span of a person's life.

Career planning is the process by which a person selects his career goals and the path to attain these goals. 'Career goals are the future positions a person strives to reach. The sequential pattern of jobs that form a career is what is known as 'career path'.[1]-[5]

Characteristics career planning:

It is a method of improving the human resources of an organization. The convergence of individual and institutional needs is the primary objective of professional development.. career planning is mutually beneficial.

Career planning is a process that takes place, as the workplace environment is never static.

Career organization is the concern of the worker, the company is required to provide the appropriate guidance and advice in

Revised Manuscript Received on December 30, 2019.

G. Santhoshkumar, Assistant professor, Department Of Science \& Humanities, Bharath Institute of Higher Education and Research ,Chennai, India. .Email santhoshravi671026@gmail.com

R. Velanganni, Assistant professor, Department Of Science \& Humanities, Bharath Institute of Higher Education and Research ,Chennai, India. .Email velangannijose78516@gmail.com

S. Robin, Assistant professor, Department Of Science \& Humanities, Bharath Institute of Higher Education and Research ,Chennai, India.Email order to obtain the best possible value from its human resource.[6]-[10]

\section{OBJECTIVES OF THE STUDY}

To study on "Career Planning and Development of Employee in Good Leather Shoes Pvt., Ltd”.

\section{A. SECONDARY OBJECTIVES:}

To analyses the contribution of the superiors in career planning of the employees.

To identify the awareness and interest level of workers towards career planning.

To identify the impact of motivation on career planning.

To identify their long term career interest

\section{B. SCOPE OF THE STUDY}

This study is made to realize the Career Planning and Development Programs in cowhide industry that may have arranged and actualized for the advancement of representatives.

It likewise endeavors to break down the perspectives and dispositions of Employees.

The inspiration levels of the bosses are fulfilled by Employees.

\section{REVIEW OF LITERATURE}

By: Bonnie Hageman (CEO, Executive advancement partners, Inc., Oklahoma City, USA) As the present work spot advances organizations are compelled to make changes inside the association so as to keep up patterns in the working environment. In an ongoing report, the BCG cooperating with the general public for HRM distinguished eight new patterns in the work environment and how organizations should move toward these changes.Christine. A. Nwuche1Hart .O. Awa2 Workers are veritable wellsprings of upper hand and arranging and building up their professions is advantageous to both the association and the representatives. This examination centers around whether associations in Nigeria offer premium to vocation arranging and improvement exercises; the projects occupied with and the apparent adequacy of projects for the most part. [11]-[15] 
Examination, which embraced a cross sectional review and used organized poll and meetings, focused on 10 firms in Rivers State, Nigeria. Information created were broke down utilizing

Spell binding insights, explicitly rates and means, and basic relapse. The outcomes show that associations perceive the need to put resources into individuals and do set out on vocation arranging and improvement programs however representatives don't see programs as excessively compelling. Additionally, in spite of the fact that organizations perceive workers as significant resources for association achievement, they don't give as a lot of regard for individual needs of representatives as they do corporate needs. This is conceivably counter profitable. Subsequently, we suggest the full fuse of workers needs in vocation improvement exercises in order to address the issues of employability of representatives and long haul aggressiveness of associations.[16]-[20]

\section{RESEARCH METHODOLOGY}

\section{A. Research Design:}

A Research Design is the game plan of conditions for accumulation and examination of information in a way that intends to join importance to the exploration reason with economy in methodology. The investigation led is Descriptive in nature. [21]-[25]

\section{B. Test Design:}

Sample Development is a constructive structure for the acquisition of an instance from a given population. It alludes to the method or process that the scientist will follow in choosing items as an example. Test Design must set out the quantity of items to be included in the example.

\section{Information Collection Method:}

Data was obtained using the Questionnaire. The questionnaire consists of a number of questions, including both an instance and a specific question connected with the subject of the investigation.

\section{Wellspring of Data:}

There are two wellsprings of information to be specific essential and auxiliary.

\section{E. Essential Data:}

Essential information is the new information that is obtained through a survey by the polling officers.

\section{F. Optional Data:}

Optional information was gathered from books, diaries and past research ponders.

Measurable Tools:

\section{G. Chi Square Test:}

This test is most broadly utilized non-parametric tests in a factual work. There might be circumstance in which it is unimaginable to expect to make any inflexible suspicion about appropriation of the populace from which tests being draws. This impediment has prompted the improvement of an elective strategies known as non-parametric tests.

To amount chi-square the greatness of the error among hypothesis and perception. Chi-square is called as pursues:

\section{Column Weight}

$\mathbf{E}=$ $\times 100$

\section{Row Weight}

$\chi^{2}$ is calculated as follows

$\sum$ (Oi - Ei) 2

$\chi^{2}=$

$\mathbf{O i}=$ Observed Frequency $\mathbf{E i}=$ Expected Frequency

In a contingency table the degree of freedom is worked out as follows.

Degree of freedom $=(\mathbf{c}-1) *(\mathbf{r}-1)$

Where,

$\mathrm{C}=$ Number of columns.

$\mathrm{R}=$ Number of Rows.

\section{Uses of Chi-square:}

To find out whether is significant difference between the two attributes.

\section{CHI-SQUARE}

\section{CHI-SQUARE TEST-I}

To test the significant association between the respondents based on skills abilities and gender.

\section{H. HYPOTHESIS}

$\mathrm{H} 0=$ There is no significant correlation between sex and age the respondents based on skills abilities.

$\mathbf{H}_{\mathbf{1}}=$ There is a significant association between the gender and the respondents based on skills abilities.

Table 1 showing the relation between skills abilities and gender

\begin{tabular}{|c|c|c|c|}
\hline Gender/workload & Male & Female & Total \\
\hline Strongly agree & 7 & 6 & 13 \\
\hline Agree & 5 & 15 & 20 \\
\hline $\begin{array}{c}\text { Neither agree nor } \\
\text { disagree }\end{array}$ & 1 & 1 & 2 \\
\hline Disagree & 2 & 9 & 11 \\
\hline Strongly disagree & 2 & 4 & 6 \\
\hline Total & 17 & 35 & 52 \\
\hline
\end{tabular}

By using the below formula we calculated expected frequency (Row total) X (column total)

\section{$\mathrm{E}=\frac{}{(\text { Grand total })}$}




\begin{tabular}{|c|c|c|c|c|}
\hline Oi & Ei & $($ Oi-Ei $)$ & $($ Oi-Ei $) 2$ & $($ Oi-E $) 2 / 5$ \\
\hline 7 & 4.25 & 2.75 & 7.56 & 1.78 \\
\hline 5 & 6.53 & -1.53 & 2.34 & 0.35 \\
\hline 1 & 0.65 & 0.35 & 0.12 & 0.18 \\
\hline 2 & 3.59 & -1.59 & 2.52 & 0.70 \\
\hline 2 & 1.96 & 0.04 & 0.061 & 0.03 \\
\hline 6 & 8.75 & -2.75 & 7.56 & 0.86 \\
\hline 15 & 13.4 & 1.363 & 2.56 & 0.19 \\
\hline 1 & 1.34 & -0.34 & 0.11 & 0.08 \\
\hline 9 & 7.40 & 1.6 & 2.56 & 0.34 \\
\hline 4 & 4.03 & -0.03 & 0.009 & 0.23 \\
\hline Total & & & & 4.74 \\
\hline & & & & \\
\hline
\end{tabular}

Degree of freedom $=(\mathrm{r}-1)(\mathrm{c}-1)$

$$
\begin{aligned}
& =(5-1)(2-1) \\
& =4 \times 1 \\
& =4
\end{aligned}
$$

The table value for 4 degree of freedom at $5 \%$ level of significance

Calculated value $\left(\chi^{2}\right)=4.74$

Tabulated value $\left(\chi^{2}\right)=9.48$

Calculated value $\left(\chi^{2}\right)<$ Tabulated value $\left(\chi^{2}\right)$

Therefore the null hypothesis is accepted and alternative hypothesis is rejected.

\section{INTERPRETATION:}

Hence there is a no significant association between the gender and the respondents based on skills abilities.

\section{RESULTS \& DISCUSSSION}

- $38 \%$ of the employees are under the age group of 18-20.

- $27 \%$ of employees are having the experience of above 5 years.

- $81 \%$ of employees are having the awareness of career planning.

- $48 \%$ of employees are expecting their job enrichment as supervisor.

- $62 \%$ of the employees are satisfied in the relationship between employers and employees.

- $50 \%$ of employees are satisfied in utilizing skill and knowledge in their job.

- $48 \%$ of employees are satisfied in improving their abilities.

- $77 \%$ of employees are having satisfied with the working environment.

- $48 \%$ of employees are satisfied of motivating the employees by management.

- $54 \%$ of employees prefer performance appraisal to increase production.

- $62 \%$ of employees are not paid fairly for their skills.

\section{SUGGESTIONS}

- Most of the employees are satisfied with superior's contribution, but still they need more support from them.

- Most of the employees are having awareness about their career planning.
- The employees having their long term interest to be Multi skilled operator. So the organization should identify the needs of the employees and support them by giving appropriate training programs to match their skills.

- The contribution levels of management in career planning towards employees are less. So the management should take necessary steps in motivating their employees to develop their career.

\section{CONCLUSION}

From the study it was found that employees needs training and development programs and also evaluate their training to identify their potential. The motivation level of the organization should be improved. The employees are mostly aware of their long term career planning but they still need support from their management. The contribution of management towards employees should also be improved. If the management is taking necessary steps to support their employees to develop their career the overall organization efficiency can be improved.

\section{REFERENCES}

1. Vasanthi, S. \& Rabiyathul Basariya, S. 2019, "Influence of value analysis and cross training in industry", International Journal of Engineering and Advanced Technology, vol. 8, no. 6, pp. 1810-1811.

2. Velvizhi, R., Sri Gowtham, S. \& Jeya Priya, D. 2019, "Examination of early feedbacks for effective product retailing on E-commerce websites", International Journal of Engineering and Advanced Technology, vol. 8, no. 6 Special Issue 2, pp. 703-706.

3. Anuradha, C., Pothumani, S. \& Kavitha, R. 2019, "A novel method towards E-commerce", International Journal of Engineering and Advanced Technology, vol. 8, no. 6 Special Issue 2, pp. 535-538

4. Thomas, J. \& Rabiyathul Basariya, S. 2019, "A study on the issues of financial ratio analysis", Indian Journal of Public Health Research and Development, vol. 10, no. 3, pp. 1079-1081.

5. Ramachandran, S. \& Rabiyathul Basariya, S. 2019, "Online marketing study on customer satisfaction and relationship", Indian Journal of Public Health Research and Development, vol. 10, no. 3, pp 1072-1078.

6. Priya, R., Vinothini, G. \& Cor Jesu, C.D. 2019, "The mentor-protégé relationship for professional growth", Journal of Advanced Research in Dynamical and Control Systems, vol. 11, no. 9 Special Issue, pp. 1110-1119.

7. Jannifer Rani, N., Bina Pani, S. \& Nimisha, N.S. 2019, "A study on money back polices available in LIC", Journal of Advanced Research in Dynamical and Control Systems, vol. 11, no. 9 Special Issue, pp. 833-839.

8. Saillaja, V., Jhansi Rani, K. \& Catherine, R. 2019, "Global marketing management planning and organization", Journal of Advanced Research in Dynamical and Control Systems, vol. 11, no. 9 Special Issue, pp. 489-493.

9. Saillaja, V., Jhansi Rani, K. \& Catherine, R. 2019, "The new phase of marketing information system", Journal of Advanced Research in Dynamical and Control Systems, vol. 11, no. 9 Special Issue, pp. 482-488.

10. Thoufiqulla \& Raju, D.V. 2019, "Perception of indian investor towards investment in mutual funds with special reference to mip funds", Journal of Advanced Research in Dynamical and Control Systems, vol. 11, no. 5, pp. 177-183.

11. Jasmine, K.R.M. \& Basariya, S.R. 2018, "A study on the customers benefits on mutual funds", International Journal of Civil Engineering and Technology, vol. 9, no. 4, pp. 45-48.

12. Vasanthi, S. \& Basariya, S.R. 2019, "Pros and cons of on the job training versus off the job training", International Journal of Scientific and Technology Research, vol. 8, no. 10, pp. 671-674. 
13. Pavithra, J. \& Ganesan, M. 2016, "A study on awareness and impact of micro-financial schemes", International Journal of Applied Business and Economic Research, vol. 14, no. 8, pp. 5449-5460.

14. Pavithra, J., Dilli Babu, P. \& Ambuli, T.V. 2014, "A study on budgetary control at Maruti Service Masters, Chennai", International Journal of Applied Business and Economic Research, vol. 12, no. 2, pp. 151-161.

15. Gunaraja, T.M. \& Venkatrama Raju, D. 2018, "Determining factors of organisational climate with reference to leadership styles", International Journal of Mechanical Engineering and Technology, vol. 9, no. 9, pp. 1327-1332.

16. Gunaraja, T.M. \& Venkatrama Raju, D. 2018, "The role of job satisfaction and training of employees in determining organisational climate of a selected industry", International Journal of Civil Engineering and Technology, vol. 9, no. 8, pp. 1266-1269.

17. Aarathy, T.S. \& Raju, D.V. 2018, "Performance appraisal and its effects on employees with respect to it sector in Chennai city", International Journal of Civil Engineering and Technology, vol. 9, no. 6, pp. 1535-1538.

18. Aarathy, T.S. \& Raju, D.V. 2018, "Employee perception towards performance appraisal system in IT sector", International Journal of Mechanical Engineering and Technology, vol. 9, no. 5, pp. 131-135.

19. Porselvi, W., Jublee, D. \& Sivanesan, G. 2018, "A study on factors influencing adoption of technology and innovation in banking industry, tamilnadu, India", International Journal of Mechanical Engineering and Technology, vol. 9, no. 5, pp. 789-800.

20. Akessa, G.M. and Dhufera, A.G., 2015. Factors That Influences Students Academic Performance: A Case of Rift Valley University, Jimma, Ethiopia. Journal of Education and Practice, 6(22), pp.55-63.

21. Miller, G. and Shih, C.C., 1999. A faculty assessment of the academic rigor of on-and off-campus courses in agriculture. Journal of Agricultural Education, 40, pp.57-65.

22. Tsinidou, M., Gerogiannis, V. and Fitsilis, P., 2010. Evaluation of the factors that determine quality in higher education: an empirical study. Quality Assurance in education, 18(3), pp.227-244.

23. Farooq, M.S., Chaudhry, A.H., Shafiq, M. and Berhanu, G., 2011. Factors affecting students' quality of academic performance: a case of secondary school level. Journal of quality and technology management, 7(2), pp.1-14.

24. Fitsilis, P., Gerogiannis, V. and Anthopoulos, L., 2014. Ontologies for software project management: a review. Journal of Software Engineering and Applications, 7(13), p.1096.

25. Adams, J.D. and Jaffe, A.B., 1996. Bounding the effects of $R \& D$ : an investigation using matched establishment-firm data(No. w5544). National bureau of economic research.

\section{AUTHORS PROFILE}

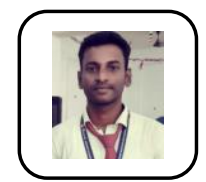

G. Santhoshkumar, Assistant professor, Department Of Science \& Humanities, Bharath,Institute of Higher Education and Research ,Chennai, India. .

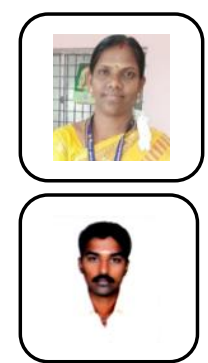

R. Velanganni, Assistant professor, Department Of Science \& Humanities, BharathInstitute of Higher Education and Research, Chennai, India

S. Robin, Assistant professor, Department Of Science \& Humanities, Bharath Institute of Higher Education and Research ,Chennai, India 